\title{
THE NBU APPROACH TO STRESS TESTING THE UKRAINIAN BANKING SYSTEM
}

\section{Yuliia Diuba}

National Bank of Ukraine

\author{
Hanna Murina, CFA
}

National Bank of Ukraine

\begin{abstract}
This paper gives a review of the stress testing methodology developed by the National Bank of Ukraine (NBU) in cooperation with the International Monetary Fund (IMF) for assessing the robustness of the Ukrainian banking sector, following one of the largest economic downturns in Ukrainian history. It starts with a brief summary of stress testing approaches and methods used throughout the world, their classifications, and key features. It then moves on to give an overview of the stress testing approach applied by the NBU, concluding with remarks as to the specificity of this approach and avenues for further development.
\end{abstract}

\section{JEL Code: G280}

Keywords: banking supervision, stress-tests, capital adequacy, credit risk

\section{Introduction}

"Risk comes from not knowing what you're doing"

- Warren Buffett

All banking regulations were born of blood. Predominantly in response to crises - either huge ones, sending economies tumbling down into squalor and despair, or less destructive ones, forcing people to tighten their belts - have new banking rules been developed. Think of the origins of Basel or the Dodd-Frank Act, to name a few. Stress tests are children of the same parents. With Ukraine being hit by the worst economic crisis in its history, it is time to get to know them better.

Stress testing is an exercise directed at measuring the resilience of a particular bank or the whole banking system to "exceptional but plausible shocks" (Čihak and Ong, 2014).

Early stress tests, used primarily as risk management tools, date back as far as the 1990s, but have come to the forefront following the financial crisis, when authorities around the world undertook measures to stabilize the financial system and increase the resilience of the banking sector. The severity of the crisis led many to question the adequacy of stress tests used prior to the crisis, as well as their ability to assess the true magnitude of risks and potential vulnerabilities. Financial Sector Assessment Programs (FSAP) conducted by the IMF and the World Bank (WB) have largely promoted the use of stress tests (Foglia, 2009). FSAPs, aimed at analyzing the resilience of the financial sector, the quality of regulatory and supervisory frameworks, and the capacity to manage and resolve crises, include stress tests as part of their toolkit (IMF website). Basel 2 requires banks to conduct their own stress tests as an important risk management tool, alerting bank management to adverse unexpected outcomes related to various risks and estimating capital that may be needed to weather a storm (BIS Working Paper, 2009). The Basel Committee on Banking Supervision (BCBS) calls for banks using an internal models-based approach for meeting market risk capital requirements to adopt comprehensive stress testing programs (Blaschke et al., 2001). The European Banking Authority (EBA), together with the European Central Bank (ECB), the Federal Reserve System (FRS), as well as various European national regulators have conducted periodic stress tests over past years. 
Stress tests are forward-looking in the sense that they aim to measure the sensitivity of a portfolio, financial institution, or the whole system to adverse shocks, which could have a significant negative impact should they occur. The aim of a stress testing exercise is thus to assess the potential effect of those shocks on banks' capital adequacy and the need for corrective action to increase resilience. Over time, stress tests came to be recognized as a powerful tool not only in risk management, but also in macroprudential and microprudential policies (see Figure 1 below). The FSAPs mentioned earlier are a good example of a macroprudential application. The IMF stress tests tend to focus on severe hypothetical scenarios, testing the financial systems' vulnerability to a major deterioration of the macroeconomic environment. The results of such tests generally do not require action on the side of the banks' management, but are used to inform the authorities of the systemic risks present (Jobst et al., 2013). Microprudential stress tests are typically conducted to examine the soundness of individual financial institutions and can result in recapitalization requirements or even bank restructuring (Jobst et al., 2013). For example, in 2010 the Federal Reserve launched the Comprehensive Capital Analysis and Review (CCAR) program to evaluate capital adequacy and internal capital planning processes of large banking groups (FRS website).

\section{Figure 1: Bank solvency stress tests*}

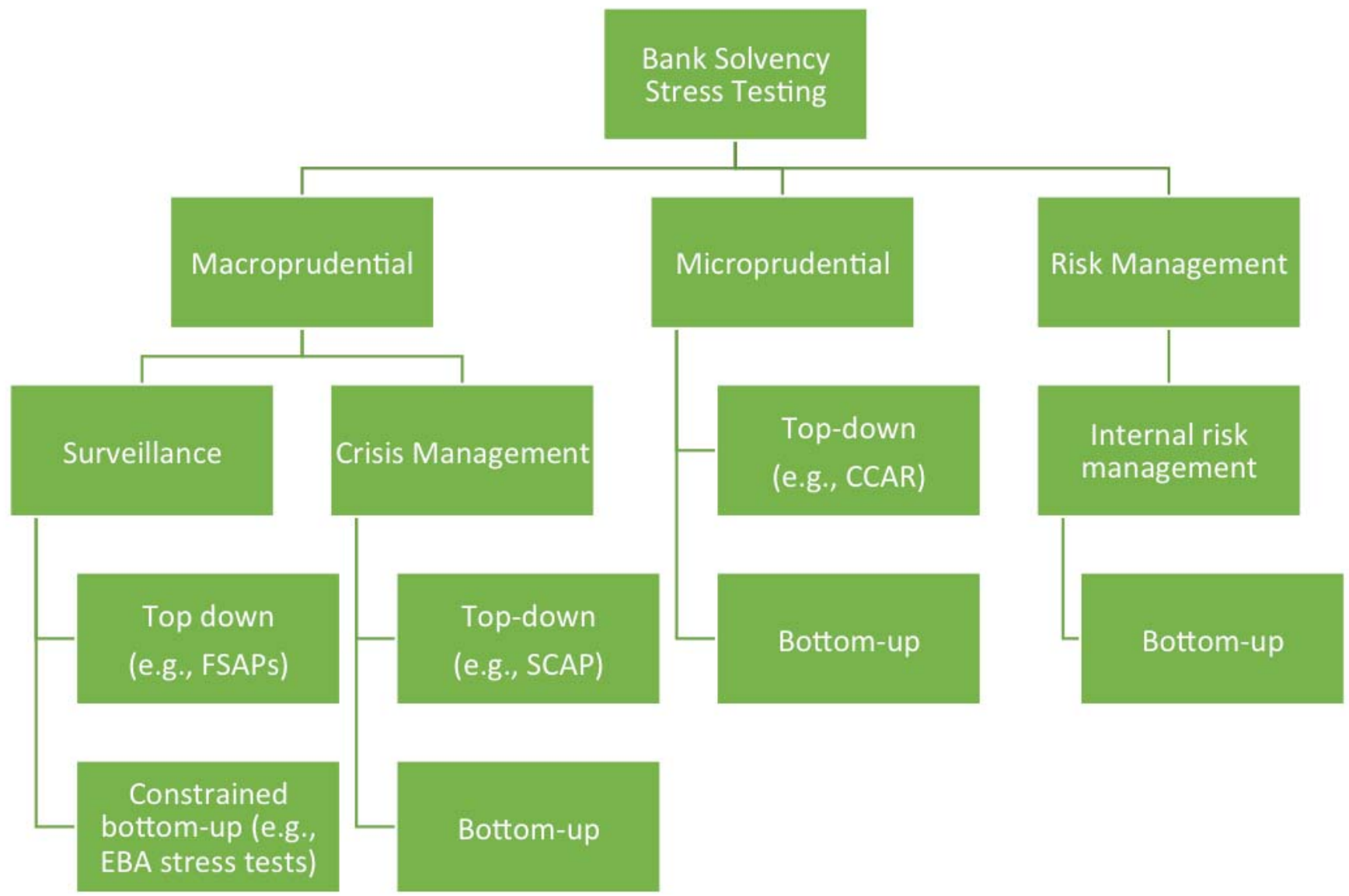

*Adapted from Jobst et al (2013).

\section{Stress testing approaches: literature review}

We shall give a brief overview of the existing approaches to banking system stress testing before moving on to discuss the methodology applied by the NBU. Numerous approaches to conducting stress tests have been developed over the years, and various classification schemes exist. Regulators across countries have come up with their own stress testing designs, built on international best practices with local variations catering to country-specific idiosyncrasies (for an example, see Table 1). 
When it comes to particular types of risks, solvency remains at the forefront of the stress testing exercises, although more and more attention is being given to developing models for testing liquidity, market, and systemic risks, as well as dynamic interaction between various types of risks. A stress test may estimate the effect of a single risk factor or model the impact of a group of risks acting simultaneously. The first approach is in essence a sensitivity analysis, the second - a scenario analysis. The scenarios selected may be based on historical data, statistical analysis, or be purely hypothetical (Blaschke et al., 2001).

\section{Figure 2. Approaches to stress-testing (IMF methodology)}

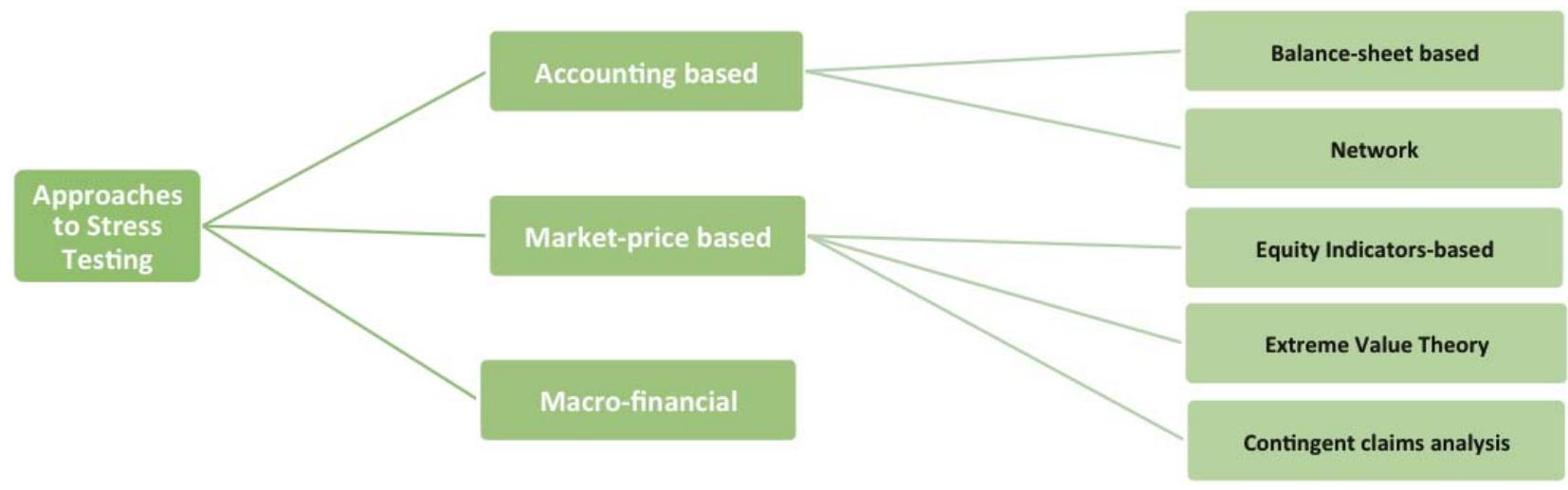

The IMF provides the following broad classification of stress testing approaches, dividing them into three categories: accounting-based approaches (including the balance-sheet approach), market-price based approaches, and macro-financial approaches (Čihak and Ong, 2014; Schmieder and Schumacher, 2014).

The accounting-based approach, as the name suggests, uses accounting data from financial statements of individual institutions or systems (Čihak and Ong, 2014). One of its most widely used variations is the balance-sheet approach, which relies on information obtained from financial statements, such as the income statements and off-balance sheet reports, as well as the balance sheet itself. This method is popular due to input data availability, financial statements being prepared regularly and usually publicly disclosed (Čihak and Ong, 2014). Additionally, financial statement information is quite standardized, which allows for peer comparison and system-wide application. Due to the granularity of the data, it is possible to use both topdown and bottom-up approaches, identifying risk drivers at the level of particular institutions as well as for the system overall (Schmieder and Schumacher, 2014). The network approach allows for tackling vulnerabilities that arise from systemic linkages between financial institutions operating in either domestic or global financial markets. Network analysis is best combined with regular stress testing exercises in order to complement the assessment of the vulnerabilities of a particular institution with analysis of the relationships between institutions and possible contagion effects (Espinosa-Vega and Sole, 2014).

As popular as they are, accounting-based stress tests have drawbacks stemming from differences in accounting standards, risks of financial statement manipulation, and the backward-looking nature of the reports (Chan-Lau, 2014). An alternative approach relies on the market's perception of risks, as reflected in the prices of financial instruments rather than accounting figures (Čihak and Ong, 2014). The Equity indicators-based approach uses information gauged from security prices in secondary markets. Although bonds and credit default swaps are a preferred source of information, their prices being more directly reflective of the issuer's creditworthiness, equities are more commonly used due to their higher liquidity and coverage. Credit default probabilities estimated from security prices can be used to assess losses under various stress scenarios (Kapinos and Mitnik, 2015). The Extreme value theory (EVT) approach focuses on identifying extreme events (tail risks) that could have an adverse impact on the financial system or separate institutions. EVT uses statistical and econometric models to assess spillover effects during a tail-risk event (Mitra, 2014). Contingent claims analysis is an approach based on a combination of balance-sheet information and forward-looking information from equity markets. It estimates credit risk based on the impact of changes in asset values related to payments on debt liabilities (Gray et al., 2014).

The Macro-financial approach promotes a holistic view on financial stability, incorporating individual institutions' soundness, their interactions between each other, and the overall economy. This method considers the links between the financial and the nonfinancial sectors of the economy and can be implemented based on both accounting and market-based data (Čihak and Ong, 2014; Maechler, 2014). 
Stress tests can be performed using either a bottom-up or a top-down approach. A bottom-up approach assumes that banks perform their own stress-tests, with the supervisor (regulator) providing guiding principles and verifying results. According to the IMF, with banks having better knowledge of their own exposures, the results of a bottom-up approach are more informative as to the risks and vulnerabilities faced by the financial institutions (Blaschke et al., 2001). When the regulator uses a centralized approach to stress testing, performing the analysis based on a single methodology and data submitted by banks, the approach is top-down. Mandatory stress testing as a regulatory requirement is relatively novel and the lack of formal prescriptions for stress test design has led to the proliferation of scientific research on this topic, with the majority of studies focused largely on the top-down approach and with bottom-up methods receiving less coverage (Kapinos and Mitnik, 2015).

The stress testing framework usually consists of several models -a major one complemented with auxiliary satellite models. As was demonstrated by the global financial crisis, the stress testing methodologies previously used were not adequate for evaluating the financial system's stability and robustness. In order to overcome the exposed weaknesses, new techniques were introduced, among them a heuristic proposed by Taleb et al. (2012) which allows assessment of how vulnerable a bank (or government) is to underestimation of tail risks. According to Taleb et al. (2012), missing convexities or non-linearities in outcomes may lead to underestimation of the impact of adverse shocks, and hence create serious fragilities in the financial system. Hence, the authors propose a heuristic that measures the sensitivity of the outcome (gains/losses) to a change in the stress applied. A financial institution would then be deemed fragile to higher volatility if the relationship between the increase in the shock applied and the losses is found to be non-linear, which is often the case for complex and interconnected markets (Taleb et al., 2012).

\section{Table 1. Select stress testing approaches: comparison table}

\begin{tabular}{|c|c|c|c|}
\hline Country & USA & EU & UK \\
\hline Timing & 2015 & 2014 & 2015 (ongoing) \\
\hline Program & DFAST & EU-wide stress test (EBA) & Bank of England stress test \\
\hline \multicolumn{4}{|l|}{ Scope } \\
\hline Bottom-up & NA & $\begin{array}{l}\text { EBA developed the stress test- } \\
\text { ing methodology, banks ran } \\
\text { the tests, local regulators pro- } \\
\text { vided support and monitoring. }\end{array}$ & \multirow[t]{2}{*}{$\begin{array}{l}\text { Banks submit their projec- } \\
\text { tions, BoE uses those submis- } \\
\text { sions as a starting point for the } \\
\text { stress test, making its own ad- } \\
\text { justments. Going forward, BoE } \\
\text { intends to give more weight } \\
\text { to its in-house models (top- } \\
\text { down approach). }\end{array}$} \\
\hline Top-down & Supervisory stress testing* & NA & \\
\hline Coverage criteria & $\begin{array}{l}\text { BHCs** with total consoli- } \\
\text { dated assets of } \$ 50 \text { billion or } \\
\text { more and nonbank financial } \\
\text { companies designated by the } \\
\text { FSOC. }\end{array}$ & $\begin{array}{l}\text { Sample of banks covering at } \\
\text { least } 50 \% \text { of the national bank- } \\
\text { ing sector in each EU Member } \\
\text { State in terms of total consoli- } \\
\text { dated assets (as of the end of } \\
2013 \text { ). }\end{array}$ & $\begin{array}{l}\text { Include all PRA-regulated } \\
\text { banks and building societ- } \\
\text { ies with total retail deposits } \\
\text { greater than } f 50 \text { billion. }\end{array}$ \\
\hline Institutions & $31 \mathrm{BHCs}$ & $\begin{array}{l}123 \text { banking groups from } 22 \\
\text { countries }\end{array}$ & $\begin{array}{l}7 \text { major UK banks and building } \\
\text { societies }\end{array}$ \\
\hline Scope of consolidation & Bank holding company & Banking group. & $\begin{array}{l}\text { At the highest level of UK con- } \\
\text { solidation }\end{array}$ \\
\hline
\end{tabular}




\begin{tabular}{|c|c|c|c|}
\hline Country & USA & EU & UK \\
\hline Data source & $\begin{array}{l}\text { Data collected by the Federal } \\
\text { Reserve on regulatory reports } \\
\text { and proprietary third-party in- } \\
\text { dustry data. }\end{array}$ & $\begin{array}{l}\text { Data collected by the national } \\
\text { authorities (regulators). }\end{array}$ & $\begin{array}{l}\text { Bank data, BoE data, and } \\
\text { third-party analytics. }\end{array}$ \\
\hline Stress testing horizon & $\begin{array}{l}9 \text { quarters (4th quarter } 2014 \\
\text { to } 4 \text { th quarter 2016) }\end{array}$ & 3 years $(2014-2016)$ & 5 years \\
\hline Scenarios & $\begin{array}{l}\text { Baseline, adverse, severely ad- } \\
\text { verse }\end{array}$ & Baseline, adverse & $\begin{array}{l}\text { Baseline scenario, annual } \\
\text { cyclical scenario, and an ad- } \\
\text { ditional scenario intended to } \\
\text { probe the resilience of the } \\
\text { system to risks that may not } \\
\text { be neatly linked to the finan- } \\
\text { cial cycle (biennial exploratory } \\
\text { scenario)***. }\end{array}$ \\
\hline $\begin{array}{l}\text { Description of the } \\
\text { stress testing approach }\end{array}$ & $\begin{array}{l}\text { Calculated projections of a } \\
\text { BHC's balance sheet, risk- } \\
\text { weighted assets (RWAs), net } \\
\text { income, and resulting regula- } \\
\text { tory capital ratios under stress } \\
\text { scenarios. } \\
\text { The four regulatory capital } \\
\text { ratios in DFAST } 2015 \text { are com- } \\
\text { mon equity tier } 1 \text {, tier } 1 \text { risk- } \\
\text { based capital, total risk-based } \\
\text { capital, and tier } 1 \text { leverage. }\end{array}$ & $\begin{array}{l}\text { Assessed the impact of risk } \\
\text { drivers on the solvency of } \\
\text { banks (focus on solvency and } \\
\text { market risks) in terms of Com- } \\
\text { mon equity tier } 1 \text { capital ra- } \\
\text { tios. }\end{array}$ & $\begin{array}{l}\text { Uses the EBA proposed frame- } \\
\text { work with certain adjust- } \\
\text { ments, including the follow- } \\
\text { ing: } \\
\text { - Static balance sheet } \\
\text { assumption (EBA) vs. } \\
\text { evolution of the size } \\
\text { and composition of the } \\
\text { balance sheet through- } \\
\text { out the scenario (BoE). } \\
\text { - Income caps and } \\
\text { expense floors (EBA) } \\
\text { vs. no such constraints } \\
\text { (BoE). } \\
\text { - Use of additiona } \\
\text { models and analysis: } \\
\text { BoE's stress test uses a } \\
\text { set of analytical tools in } \\
\text { addition to participat- } \\
\text { ing banks' own pro- } \\
\text { jections to assess the } \\
\text { impact of scenarios on } \\
\text { banks' profitability and } \\
\text { capital ratios. }\end{array}$ \\
\hline Disclosure & $\begin{array}{l}\text { Detailed disclosure of individ- } \\
\text { ual bank results (required un- } \\
\text { der the Dodd-Frank Act)***. }\end{array}$ & $\begin{array}{l}\text { Disclosure of aggregate results } \\
\text { by country (EBA). Each local } \\
\text { regulator discloses reports on } \\
\text { individual bank results. }\end{array}$ & $\begin{array}{l}\text { Detailed disclosure of aggre- } \\
\text { gate bank results (consoli- } \\
\text { dated for the whole banking } \\
\text { sector), capital-ratio data on } \\
\text { individual banks. }\end{array}$ \\
\hline
\end{tabular}

* Under the Dodd-Frank Act, select financial institutions are also required to conduct annual/semi-annual company-run stress tests.

** BHC - Bank holding company.

*** The Dodd-Frank Act also requires BHCs to disclose summaries of their company-run stress test results.

**** All banks are also required to run a broad range of stress tests and scenario analyses relevant to their business models as part of their ICAAP (the results are not made public).

Sources: Bank of England (2015), Bank of England (2014), FRS website, EBA (2014), EBA (2015), FRS (2015) 


\section{NBU approach to stress-testing Ukrainian banking system}

On 24 April 2015, the NBU initiated a diagnostic study of the Ukrainian banking system as a mandatory part of the UkraineIMF cooperation program under the Extended Fund Facility (EFF) agreement. The goal of this study was to evaluate the quality of banks' asset portfolios and estimate their potential capital needs over the three-year period of 2015-2017. The first part of the exercise consisted of an asset quality review (AQR) laying the foundation for the second part - the stress test. Data obtained from on-site teams (inspections) was used as a major input for the stress tests, along with data from NBU registers and the banks themselves.

\section{Design of the stress test}

The NBU stress test was focused primarily on assessing Ukrainian banks' solvency under the stress scenario applied, evaluating credit risk (including on- and off-balance sheet exposures, positions on the banking and trading books), and interest rate spreads risk, currency risk and risk of large exposure concentration in loan portfolios.

The stress test covered the 20 largest Ukrainian banks and was run at the highest level of domestic consolidation, the scope of consolidation being the perimeter of the banking group. The exercise included domestic exposures, with special attention given to large banking and trading book positions. All data inputs were fixed as of the date 31 March 2015 and projections were made for the three-year forecast period of 2015-2017. Unlike the more common multi-scenario approach, the NBU used a single baseline macroeconomic scenario, which was developed in cooperation with the IMF. The rationale behind the decision to give up adverse stressed scenarios was the fact that Ukraine was already at the nadir of an economic crisis, thus making application of additional macroeconomic shocks an unrealistically severe scenario. The baseline scenario used assumed a gradual recovery of the Ukrainian economy starting in 2016.

Projections of some of the key variables are presented in the table below. Approaching the end of 2015, it is clear that the macroeconomic projections for the relevant year were in line with actual developments.

\section{Table 2. The baseline scenario}

\begin{tabular}{|c|c|c|c|c|c|}
\hline & & 2014 & 2015E & 2016E & 2017E \\
\hline 1 & Real GDP, chg. YOY & $(6.8 \%)$ & $(9.0 \%)$ & $2.0 \%$ & $3.5 \%$ \\
\hline 2 & GDP deflator, YOY & $14.8 \%$ & $39.0 \%$ & $12.0 \%$ & $9.9 \%$ \\
\hline 3 & Nominal GDP, chg. YOY & $7.0 \% 0$ & $26.4 \%$ & $14.2 \%$ & $13.7 \%$ \\
\hline 4 & Interbank UAH/USD, EOP & 15.8 & 23.5 & 24.4 & 24.9 \\
\hline 5 & Interbank UAH/USD, AFP & 12.0 & 22.0 & 24.1 & 24.7 \\
\hline 6 & CPI inflation, YOY & $24.9 \%$ & $45.8 \%$ & $12.0 \%$ & $8.0 \%$ \\
\hline 7 & Core CPI inflation, YOY & $22.8 \%$ & $35.0 \%$ & $8.5 \%$ & $6.1 \%$ \\
\hline 8 & PPI inflation, YOY & $31.8 \%$ & $31.8 \%$ & $12.5 \%$ & $10.9 \%$ \\
\hline 9 & Credit interest rate, UAH & $17.2 \%$ & $21.1 \%$ & $15.8 \%$ & $13.7 \%$ \\
\hline 10 & Deposit interest rate, UAH & $11.7 \%$ & $12.9 \%$ & $9.3 \%$ & $7.6 \%$ \\
\hline 11 & Credit interest rate, FX & $8.7 \%$ & $8.3 \%$ & $8.4 \%$ & $8.5 \%$ \\
\hline 12 & Deposit interest rate, FX & $6.7 \%$ & $6.5 \%$ & $5.8 \%$ & $5.5 \%$ \\
\hline 13 & Monthly avg. wage, UAH & 3,480 & 4,256 & 4,958 & 5,628 \\
\hline 14 & Real wage, chg. YOY & $(6.5 \%)$ & (18.5\%) & $2.0 \%$ & $3.3 \%$ \\
\hline 15 & Unemployment rate (ILO) & $9.3 \%$ & $11.5 \%$ & $11.0 \%$ & $9.4 \%$ \\
\hline
\end{tabular}


The expected result of the exercise consisted of estimating the need for additional Tier 1 capital and total regulatory capital for the 2015-2017 period for each of the 20 banks, with subsequent submission of capitalization plans.

\section{Model framework}

The NBU used a balance-sheet stress testing approach, relying on information provided by banks, adjusted following the AQR stage and on-site reviews. The framework consisted of three models. Two of them were essentially satellite models - the large exposures (LE) model and the portfolio-based model - providing inputs into the main bank balance sheet (BS) model. Relationships between the models are illustrated in the figure below.

\section{Figure 3: Relationship between the three stress test models}

The difference of the current NBU approach as compared to the stress tests conducted in 2014 was the separation of all exposures into three categories: sovereign and parastatals, large exposures, and the remaining exposures. Large exposures were defined as those above UAH 200 million or 5\% of the bank's regulatory capital (RC), whichever was smaller. All loans of the bank, as well as its positions in fixed income securities satisfying the aforementioned size criteria, excluding sovereign exposures, were analyzed by means of a separate excel model. Financial performance of the bank's large borrowers was modelled over the forecast period of 2015-2017. Loan migrations to/from the non-performing (NPL) category and the corresponding change in loan loss provisions were then estimated. All other exposures that did not qualify as large were modelled on a portfolio basis, using econometric techniques to forecast loan migrations and changes in provisions. The practice of analyzing large exposures on an individual basis is not common among national regulators, partly due to significant resource and time requirements. Conducting individual stress-testing of large exposures by the NBU was important due to:

1. High concentration of large exposures in banks' portfolios;

2. Concerns about lending to related parties;

3. Differences in borrowers' credit ratings and overall loan quality across banks;

4. Low level of ownership structure transparency.

Modelling large exposures on an individual basis allowed accounting for disparities in asset and collateral quality across Ukrainian banks.

\section{Exposures stress tested on a portfolio basis}

In order to compose relatively uniform groups of borrowers with similar characteristics, the loan portfolio was structured into sub-portfolios according to the diagram below.

Exposures to the public sector and parastatals were not stress tested. Loans to other corporate clients (not classified as large) and households were stress tested on a portfolio basis. 


\section{Figure 4: Stress testing approaches to loan portfolio components}

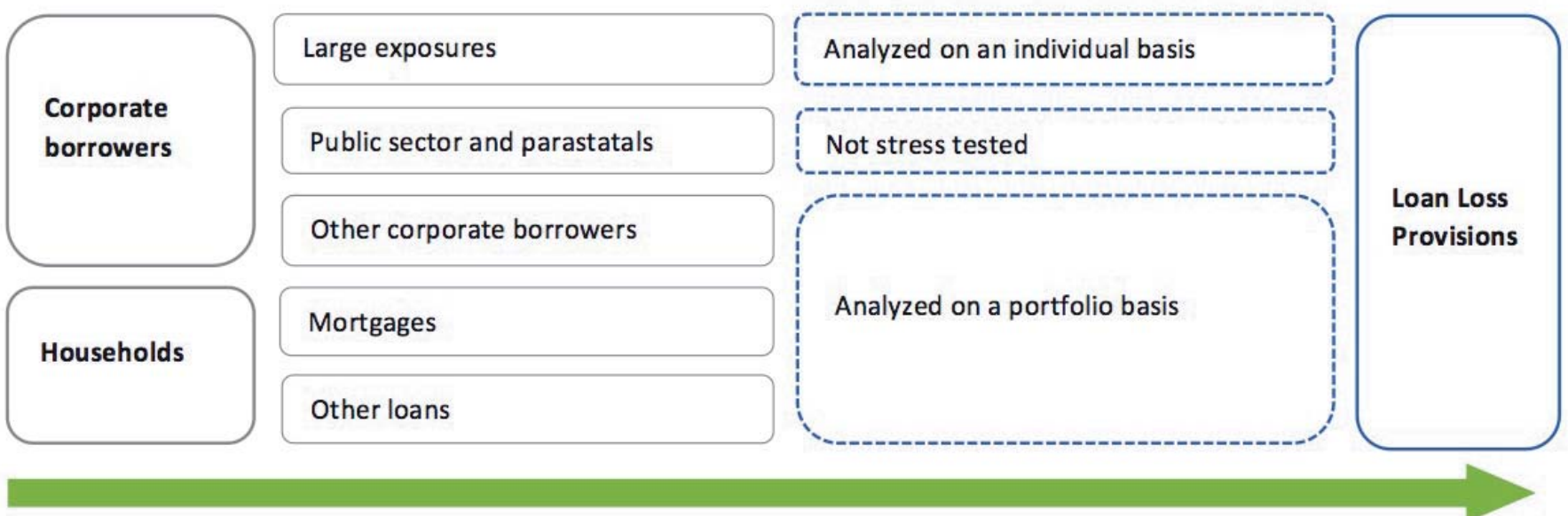

The NBU used multi-factor ordinary least squares linear regression models to forecast changes in NPL shares for each of the six exposure segments (UAH/FX; other corporate/mortgages/other retail). Change in share of NPLs was the dependent variable and changes in macroeconomic indicators - the explanatory variables. The macroeconomic factors used included real GDP, CPI, credit and deposit interest rates in national and foreign currencies, UAH/USD exchange rate, nominal wage, and unemployment rate. Regression parameters were estimated based on quarterly data collected over the 2006-2014 period. Projections of NPL share changes for each segment were then applied to the actual levels of NPL shares at each bank. For loans having migrated into the NPL category, historical provisioning levels (as confirmed or re-estimated by the AQR) were used, but not less than specified minimal levels (55\%-70\%).

\section{Stress testing large exposures}

The framework for stress testing large exposures was determined by NBU regulations, based on Basel principles, as well as international practices in stress testing.

According to NBU regulations, there are five credit quality categories, with the fourth and fifth categories deemed nonperforming. Based on the AQR, large exposures were first classified as either performing (going concern) or non-performing (gone concern). Only loans that fell into the first to fourth categories were stress tested, with loans from the fifth category retained as part of the loan portfolio throughout the 2015-2017 period with adjustments for exchange rate changes. According to Resolution No. 23, ${ }^{1}$ a failure to meet certain regulatory requirements (e.g., timely submission of financial statements) may result in a downgrade of a going concern loan to the fourth category. This way, the fourth category was also stress tested so as to avoid exclusion of essentially performing loans.

According to NBU regulations, a loan's probability of default (PD) is determined by its credit quality category, taking into account forward looking qualitative and quantitative factors which define the borrowers' ability to repay debt during the loan contract. The credit quality category in its turn is determined by a combination of two criteria - the financial class of the borrower and its debt service discipline. The financial class of the borrower is based on its financial state (represented by relevant financial ratios). Debt service discipline is determined by registered timeliness/delinquency in interest and principal repayments as well as ability to service debt.

Projecting the borrowers' financial state over the 2015-2017 period implied assigning them to one of nine classes based on the value of their integral indicators (estimated as a linear combination of certain financial ratios) within the ranges specified for each industry and borrower size. In order to calculate the financial ratios used to arrive at the integral indicator, the borrowers' financial performance was modeled based on data for the 2013 and 2014 full fiscal years and the first quarter of 2015. The following major assumptions were made:

${ }^{1}$ NBU Resolution №23 (25.01.2012) on loan loss provisioning. 
- Changes in the financial performance of borrowers are largely driven by changes in macroeconomic factors. For example, revenue projections are linked to nominal output growth, approximated by GDP, and CPI/PPI.

- Changes in balance sheet items are driven by relevant income statement items.

- Change of forecasted debt amount is determined by debt amortization and funding needs (estimated as short-term loans).

- Projections are solely based on historic data, excluding any future income/expenses related to implementation/ termination of business projects, optimization initiatives and/or new client acquisitions.

A borrowers' debt service discipline for 2015-2017 was estimated based on the projected cash flows for each period and scheduled amounts of debt repayments. In case of estimated cash flow deficiency, debt service discipline was expected to deteriorate, but not more than 1-2 notches below the current level: one notch-for regular borrowers, two notches for highrisk profile borrowers.

\section{Figure 5: Probability of default estimation}

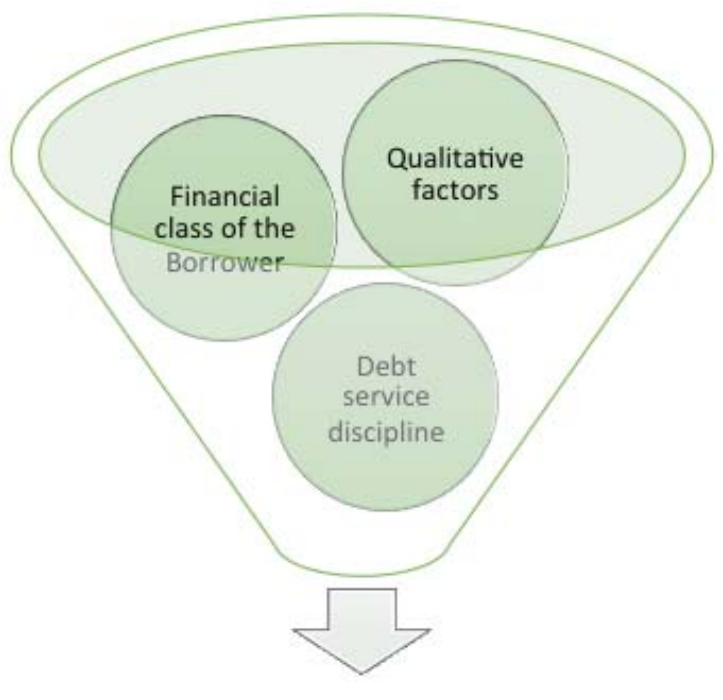

Probability of default

In estimating default probabilities, the following qualitative factors were also taken into account: the availability of audited financial statements, risk profile, and history of business activity. When evaluating the risk profile of a borrower, measures such as debt to sales ratio and the number of employees were considered.

Following Resolution No. 23 and Basel principles, Loan loss provisions (LLP) were estimated at the level of expected losses (EL) from credit operations, determined by the size of exposure at risk, probability of the borrower defaulting, and the amount and quality of collateral pledged.

$$
E L_{i}=E A D_{i} \times P D_{i} \times L G D_{i}=P D_{i} \times\left(E A D_{i}-\text { Collateral value } \text { adj }_{._{i}}\right)
$$

Where $L G D_{i}=1-R R_{i}=1-\frac{\text { Collateral value ad } j_{\cdot i}}{E A D_{i}}$

$E A D_{i}-$ Exposure at Default,

$P D_{i}$ - Estimated probability of default;

$L G D_{i}$ - Loss given default; 
$R R_{i}$ - Recovery rate;

Collateral value adj. - collateral value adjusted for liquidity risk and expenses for collateral enforcement and selling.

The stress testing methodology allowed the use of consolidated financial statements for borrowers which were part of larger business groups, moving toward a broader understanding of the risks pertinent to those borrowers.

Under the NBU stress testing approach, credit quality and default probability of a corporate borrower were largely influenced by the borrower's financial standing, as is the typical practice in stress testing exercises. This way, the regulator analyzed the company's ability to internally generate cash flow for debt servicing purposes, rather than simply recognize the timeliness of payments (debt service discipline).

\section{Bank model: BS and Profit and loss projections}

For the purpose of stress-testing, forecasts of banks' financial statements (balance sheet and P\&L statement) were made covering three years $-2015,2016$, and 2017. A key assumption underlying the stress testing methodology was that of the fixed balance sheet and business mix. Both the asset structure and the funding structure of the banks would remain unchanged over the time horizon of the exercise. It was assumed that assets and liabilities that matured within the forecast period would be replaced with similar financial instruments in terms of type and credit quality. Thus, balance sheet changes would only be driven by:

- Exchange rate changes (Assets, Liabilities);

- $\quad$ Asset quality changes (Assets);

- Irrevocable off-balance sheet credit facilities drawdown for large (Assets) borrowers;

- $\quad$ Retained earnings changes from income/loss in the period (Equity).

It was assumed that over the stress testing horizon, the banks would refrain from paying out dividends to their shareholders and/or repaying their subordinated debt.

The income statement forecast included loan loss provisions charges, estimated using the satellite models (individually for large exposures and on a portfolio basis for all other exposures), as well as other income/expense items. An adjustment for interest rate sensitivity gap, interest rates pass-through effect, and corrections for one-off items were made. Incorporating the pass-through effect in the model allowed accounting for differences in interest rate movements across various assets and liabilities. Application of a gap model accounted for the risks arising from a mismatch in the rate sensitivity of the bank's assets and liabilities.

The gap effect was taken into account for assets and liabilities which matured (fixed rate instruments) or whose interest rates were repriced (floating rate instruments) over the short-term horizon of one year. All interest sensitive assets and liabilities were allocated to separate "time buckets" depending on their maturity/time of repricing (Blaschke et al (2001)). The projected interest rate income reflected repricing effects (changes in interest rates) for the new positions and changes in the reference rates for the floating rate items. A simplified formula for calculating adjustment for interest rate sensitivity gap $\left(\Delta \mathrm{NII}_{\mathrm{t}}^{\mathrm{g}}\right)$ is presented below.

$$
\Delta N I I_{t}^{g}=\sum_{i=1}^{k}\left(\left(A_{i, t} \times \Delta R_{a, t}-L_{i, t} \times \Delta R_{l, t}\right) \times\left(\frac{\text { start }_{i}+e n d_{i}}{2 \times 360}\right)\right)
$$

$\mathrm{R}_{a / l, t}$ - Effective interest rate on asset a (liability $/$ ) class for the time period $t$;

$\Delta \mathrm{R}_{a / l, t}$ - Change in weighted average effective interest rate on assets/liabilities assuming a parallel shift in loan and deposit interest rates;

$\mathrm{A}_{a, t}, \mathrm{~L}_{l, t}-$ Average interest-sensitive asset/liability class for the time period $\mathrm{t}$;

$\frac{\text { start }_{i}+e n d_{i}}{2 \times 360}-$ Maturity adjustment factor (period midpoint) defined according to table 3 . 
Table 3. Interest rate sensitivity structure

\begin{tabular}{|l|l|l|l|}
\hline Maturities & Start & End & Adjustment factor \\
\hline Demand & 0 & 0 & 0.000 \\
\hline $0-1$ months & 0 & 30 & 0.042 \\
\hline $1-3$ months & 30 & 90 & 0.167 \\
\hline 3-6 months & 90 & 180 & 0.375 \\
\hline 6-12 months & 180 & 360 & 0.750 \\
\hline above 12 months & 360 & NA & 1.000 \\
\hline
\end{tabular}

\section{Bank model: estimating capital requirements}

For each forecast period the amount of Tier 1 capital was estimated as the sum of Tier 1 capital from the previous period and net income in the current period, with certain adjustments. If Tier 1 ratio in any given period fell below the required threshold, a capital gap was identified.

\section{Table 4. Estimating capital gap in 2015-2017}

\begin{tabular}{|c|c|c|}
\hline 2015 & 2016 & 2017 \\
\hline $\begin{array}{c}\text { Tier } 1 \text { capital (Q1 2015, after AQR- } \\
\text { based adjustments) }\end{array}$ & Tier 1 capital (2015, EOP) & Tier 1 capial (2016, EOP) \\
\hline+ & + & + \\
\hline Operating profit & Operating profit & Operating profit \\
\hline- & - & - \\
\hline Loan loss provisions change & Loan loss provisions change & Loan loss provisions change \\
\hline$+/-$ & $+/-$ & $+/-$ \\
\hline other adjustments & other adjustments & other adjustments \\
\hline$\div$ & $\div$ & $\div$ \\
\hline RWA(after AQR-based adjustments) & RWA $(2015$, EOP $)+$ Changes in RWA & RWA $(2016, E O P)+$ Changes in RWA \\
\hline$=$ & $=$ & $=$ \\
\hline Tier 1 ratio (2015) & Tier 1 ratio (2016) & Tier 1 ratio (2017) \\
\hline
\end{tabular}

Total regulatory capital was estimated as the sum of Tier 1 and Tier 2 capital, minus deductions. According to Ukrainian banking regulations, the amount of Tier 2 capital included in the regulatory capital should not exceed Tier 1 capital (Tier2 $\leq$ Tier 1). Many Ukrainian banks satisfy Tier 2 requirements through issuance of subordinated debt. Over the forecast periods, the amount of subordinated debt was fixed at the level reported as of 1 April 2015, adjusted for changes in foreign exchange rates (for debt denominated in foreign currency) and amortization schedules (according to Ukrainian regulations).

If the results demonstrated that Tier 1 capital and total regulatory capital were not sufficient to absorb the shocks under the stress testing scenario, the NBU requested banks to submit recapitalization plans to meet minimum capital requirements. The schedule for submission of such plans and their implementation was developed by the NBU in accordance with the IMF memorandum. ${ }^{2}$ Minimal capital requirements and milestones under this agreement are outlined in the table below.

\footnotetext{
${ }^{2}$ The agreement under the current EFF program between Ukraine and the IMF.
} 


\section{Table 5. Minimal capital adequacy ratios}

\begin{tabular}{|l|c|c|}
\hline & 2016 & 2017 \\
\hline Tier 1 capital & $4 \%$ & $6 \%$ \\
\hline Regulatory capital & $5 \%$ & $7 \%$ \\
\hline
\end{tabular}

\section{Future developments}

The current NBU stress testing methodology allowed execution of a thorough multilateral analysis of the largest Ukrainian banks' financial resilience, based on which action would be taken to strengthen capital adequacy. As economic conditions evolve, the stress testing methodology will need to be updated and improved.

One area of further development is the addition of adverse macroeconomic scenarios. In 2015, Ukrainian banks were stress tested based on a baseline scenario, which is in essence a projection of the current state of the economy into the forecasted period. In the future, it will be necessary to introduce more scenarios, including adverse and severely adverse scenarios, as well as to test the financial system for specific shocks, the impact of which could be material.

Inclusion of other types of risks (liquidity, market, etc.) into the stress testing exercise, either together with the solvency test or as separate exercises, would be highly beneficial for a more comprehensive understanding of financial institutions' resilience to potential shocks.

The specificity of Ukraine's financial system, which is characterized by a relatively small interbank market, practically nonexistent securities markets, and a high concentration of banks' asset portfolios in traditional lending to corporate and retail clients, has influenced the design of the stress test. As the system evolves, more sophistication will be required within the stress testing models.

As Ukraine moves towards higher transparency and convergence with international banking standards, more disclosures regarding stress testing methods, as well as stress test results, will be required. Those issues remain sensitive for the banking community and the transition would need to be gradual and prudent.

\section{Conclusions}

This paper gives a review of the stress testing methodology that has been developed by the NBU in cooperation with the IMF for the purpose of assessing robustness of the local banking sector. The stress testing framework incorporated experiences and practices of foreign regulatory authorities and supranational organizations responsible for financial stability. Building on the large body of scientific research covering various aspects of the stress testing process, NBU adapted its methodology for idiosyncrasies present in the local economic and business environment. Being forward-looking by design, it focused on estimating expected losses on large exposures portfolios. Moreover, in certain aspects the stress testing approach allowed analysis of consolidated financial statements for borrowers which were part of larger business groups, thus moving towards a broader understanding of the risks pertinent to those borrowers.

Under the NBU stress testing approach, credit quality and default probability of a corporate borrower were largely influenced by the borrower's financial standing. This way, the regulator analyzed the company's ability to internally generate cash flow for debt servicing purposes, rather than simply recognize the timeliness of payments. Such an approach allowed to focus on the viability and sustainability of the borrower's business and proved more reliable in terms of evaluating credit quality.

In order to account for borrower characteristics influencing credit risk, the methodology broadened the use of qualitative factors. Factors evaluated included the borrower's staff size, years operating, and audit of the financial statements.

The decision to stress test large borrowers of banks on an individual basis proved justified. Modelling the borrowers' financial performance over a 3-year horizon allowed assessment of their capacity to service and repay their loans, thus giving a more realistic picture of a particular bank's NPL rate across a large exposures portfolio. 
These, and other additions and modifications to the current NBU stress testing methodology, helped improve the quality of the analysis and subsequent recommendations. But it is a work in progress; as the Ukrainian financial system evolves, stress testing models and approaches will need to be further updated. Economic ups and downs are inevitable, adverse shocks are unpredictable, and no tool, however sophisticated, can fully guard against them. Despite these facts, stress tests represent a reliable compass for navigating us towards the safe shores of financial stability. They are well worth befriending.

\section{References}

- Bank of England (2014). Stress testing the UK banking system: 2014 results.

- Bank of England (2015). The Bank of England's approach to stress testing the UK banking system.

- Bank for International Settlements (2009). Principles for sound stress testing practices and supervision. Available at: http://www.bis.org/publ/bcbs155.pdf

- Blaschke W., Jones M., Majnoni G., Peria S.M. (2001). Stress testing of financial systems: an overview of issues, methodologies, and FSAP experiences. Working Paper, IMF, No. 01-88.

- Chan-Lau, Jorge A. (2014). Introduction to the equity indicators-based approach to stress testing. A Guide to IMF Stress Testing: Methods and Models, IMF, Washington D.C.

- Clark T.P., Ryu L.H. (2015). CCAR and Stress Testing as Complementary Supervisory Tools. Available at: https:// www.federalreserve.gov/bankinforeg/ccar-and-stress-testing-as-complementary-supervisory-tools.htm

- Čihak M. (2014). Stress tester: a toolkit for bank-by-bank analysis with accounting data. A Guide to IMF Stress Testing: Methods and Models, IMF, Washington D.C.

- Čihak M., Ong L.L. (2014). Stress Testing at the International Monetary Fund: Methods and Models. A Guide to IMF Stress Testing: Methods and Models, IMF, Washington D.C.

- Dodd-Frank Act Stress Test 2015: Supervisory Stress Test Methodology and Results (2015). Federal Reserve Board.

- Espinosa-Vega M.A., Sole J. (2014). Introduction to the Network Analysis Approach to Stress Testing. A Guide to IMF Stress Testing: Methods and Models, IMF, Washington D.C.

- European Banking Authority (2014a). Methodological note EU-wide stress test 2014.

- European Banking Authority (2014b). Results of 2014 EU-wide stress test.

- Foglia A. (2009). Stress testing credit risk: a survey of authorities' approaches. International Journal of Central Banking, Vol. 5, No. 3, pp. 9-45.

- Gray D.F., Andreas A.J., Cheng H.L., Yingbin X. (2014). Introduction to the contingent claims analysis approach for stress testing. A Guide to IMF Stress Testing: Methods and Models, IMF, Washington D.C.

- IMF (2015). Financial Sector Assessment Program.

- Jobst A., Li L.O., Christian S. (2013). A framework for macroprudential bank solvency stress testing: application to S-25 and other G-20 Country FSAPs. Working Paper, IMF, No. 13-68. https://doi.org/10.5089/9781616355074.001

- Kapinos P., Oscar M. (2015). A top-down approach to stress testing banks. Working Paper, No. 2015-02, FDIC. https://doi.org/10.2139/ssrn.2608440

- Maechler A. (2014). Introduction to the macro-financial approach to stress testing. A Guide to IMF Stress Testing: Methods and Models, IMF, Washington D.C.

- Mitra S. (2014). Introduction to the extreme value theory approach to stress testing. A Guide to IMF Stress Testing: Methods and Models, IMF, Washington D.C.

- Schmieder C., Schumacher L. (2014). Introduction to the balance sheet-based approach to stress testing. A Guide to IMF Stress Testing: Methods and Models, IMF, Washington D.C.

- Taleb N., Canetti E., Kinda T., Loukoianova E., Schmieder C. (2012). A new heuristic measure of fragility and tail risks: application to stress testing. Working Paper, No. 12-216, IMF, Washington D.C. https://doi.org/10.2139/ssrn.2155770 